\title{
Ensuring Sustainable Development of Local Self- Government: Foreign Experience for Ukraine
}

\author{
By Viktor Ladychenko ${ }^{1}$, Olena Gulac ${ }^{2}$, Karim Yemelianenko ${ }^{3}$, Yurii Danyliuk ${ }^{4}$, \\ Volodymyr Kurylo
}

\begin{abstract}
In order to build effective democratic governance under the Council of Europe Action Plan for Ukraine, local governments and elected representatives must have the knowledge and tools to manage modern and efficient resources, and local governments in general must increase their transparency, activities to strengthen citizens' trust in local political institutions. In its ambitious plans to implement effective governance, the Government of Ukraine is working to create a modern system of local selfgovernment that promotes the dynamic development of regions and transfers as much power as possible to the level closest to citizens - communities. The article is devoted to the issue of ensuring the sustainable development of local self-government in Ukraine on the basis of the experience of building the system of local self-government in the European countries. Foreign experience with the existing system of local governments of Ukraine is compared. Local governments are classified into representative and executive. The practice of organizing their activities is studied. Both regional and local representative bodies and municipalities were studied. Different types of individual and collegial executive bodies of local self-government of foreign countries, methods of their formation, management models are given. The real state of the results of the reform of local self-government and decentralization, as well as the administrative-territorial system in Ukraine has been established. The main positive features of the system of local self-government bodies of foreign countries are identified and options for implementing sustainable development methods for self-government of Ukraine are proposed, including through effective state control, election of key local government officials, codification of local self-government legislation and balancing the status and powers of representatives and executive bodies of local self-government.
\end{abstract}

Keywords: local government, representative body, executive authority, international experience, local deputies, mayor, management model

\section{Introduction}

Ukraine is a European country that has been a member of the Council of Europe since 1995 and is committed to European standards, in particular in the field of local and regional democracy. It ratified the European Charter of Local Self-Government in 1997

\footnotetext{
${ }^{1}$ Doctor of Law, professor, head of the Department of International Law and Comparative Law of the National University of Life and Environmental Sciences of Ukraine

2Doctor of Law, Associate Professor, Associate Professor of the Department of Administrative and Financial Law of the National University of Life and Environmental science of Ukraine

${ }^{3} \mathrm{PhD}$ in Law, Senior Lecturer of the Department of Theory and History of State and Law of the National University of Life and Environmental science of Ukraine

${ }^{4} \mathrm{PhD}$ in Law, Senior Researcher, Head of the Sector of Draft Law Works, Department of Problems of Development of the National Legislation of Legislation Institute of the Verkhovna Rada of Ukraine

${ }^{5}$ Doctor of Law, professor, head of the Department of Administrative and Financial Law of the National University of Life and Environmental science of Ukraine
} 
and the Additional Protocol on the Right to Participate in the Affairs of Local SelfGovernment in 2014. Reform of local self-government and decentralization has remained a priority on the political agenda in Ukraine since 2014 (Council of Europe, 2020). Today Ukraine is already a country of communities. In 2020, a new administrative-territorial structure of the basic and subregional level was approved and instead of 11,694 village, settlement and city councils, the Government of Ukraine formed 1,469 territorial communities, and instead of 490 districts, the Ukrainian parliament formed 136, and local elections have already taken place. To ensure the sustainable development of communities, the separation of powers between levels of government on the principle of subsidiarity has been announced (On decentralization reform, 2020). In order to build effective democratic governance under the Council of Europe Action Plan for Ukraine, among the expected results of the reforms, in particular, local governments and elected representatives must have the knowledge and tools to manage modern and efficient resources, and local governments in general must increase their transparency. activities to strengthen citizens' trust in local political actors and institutions (The Council of Europe Action Plan for Ukraine, 2018). In its ambitious plans to implement effective governance, the Government of Ukraine is working to create a modern system of local self-government that promotes the dynamic development of regions and transfers the maximum possible number of powers to the level closest to citizens - communities (Government portal, 2020). In Ukrainian society, including among scientists, there is a live discussion on further ensuring the sustainable development of local self-government. Therefore, ensuring the sustainable development of local self-government in Ukraine on the basis of foreign experience in building a system of local self-government is important and relevant.

\section{The Approaches to Understanding Local Government and Governance}

According to scientists, today there is no universal model or methodology in the world that could be fully and unchanged applied in Ukraine (Golovko, 2017; Kidalov, 2020; Krasnova, 2020; Kutsevych, 2020; Ladychenko, 2017; Pihul, 2016; Shulga, 2020; Yara, 2021). But to ensure the sustainable development of local government are interesting results of research by scientists in which the main criteria for the classification of local governments used functions, method of formation, scope of powers and decision-making (Golovko, 2019; Dubchak, 2020; Kachur, 2020; Shvets, 2014; Vasiuk, 2020). The approach to understanding local government and governance varies from country to country. According to O.O.Petryshyn, such differentiation was preceded by a number of factors, in particular: 1) objective historical development of the state; 2) its international relations and cooperation (as well as periods of isolation, wars, etc.); 3) trends in political development and class struggle; 4) processes of globalization, etc. (Petryshyn, 2014). Despite significant political, legal, economic, administrative, social and cultural differences compared to other countries, scholars recognize that the structure and policy of local government, as well as mechanisms for resolving conflicts between levels of government are common in all countries (Tkachuk, 1997). In our opinion, despite the post-socialist past, today in Ukraine local self-government is given one of the key values. For its further development it is necessary to study both European and world practice of local selfgovernment. 
The names of self-governing entities in each country are different: district, union of communities, community (Germany), rural and urban municipalities (Spain, Portugal), communes (France, Italy, Sweden), parishes (Great Britain), counties, cities, gminas, villages (Poland), counties and cities (Estonia), etc. (Kaminska, 2014).

For systems of local self-government is characterized by the division of local government into two main elements (Shvets, 2014):

- representative body;

- executive authority.

At the same time, the representative body of local self-government is an integral part of local self-government, which has decisive powers. They function at the local (municipal) and middle (regional) levels (Shvets, 2014).

Regional representative bodies often perform general issues of infrastructure development in the region (Funta, 2016; Ladychenko, 2013; Yara, 2018), general corporate functions in relation to lower-level representatives, and adopt the budgets of territorial units (Golovko, 2020; Ladychenko, 2018). They are elected for a term of 2 - 6 years: in Sweden (landstings) - for 3 years; in Germany (kraystags) - for 4 years; in France (general councils in departments) - for 6 years (Shvets, 2014; Petryshyn, 2014; Pittsyk, 2006). In Ukraine, such regional representative bodies are oblast (regional) and rayon (district) councils, which are elected for 5 years. However, unlike Western countries, regional councils in Ukraine still do not have their own executive bodies. The functions of executive bodies are performed by local state administrations, which have little dependence on regional representative bodies. In this aspect, the Ukrainian model of regional governance is more similar to the centralized models of such post-socialist countries as Belarus and Kazakhstan. Comparing the models of local self-government of Ukraine and Kazakhstan K.O.Emelyanenko substantiates the need for legislative delimitation of powers of local representative and executive bodies in the Republic of Kazakhstan, where "local government and selfgovernment" is carried out by representative (maslikhats) and state executive (akimats) bodies, with a clear advantage of the state executive bodies. The same problem exists in Ukraine, where, for example, deputies of the district council (representative body) delegate part of their powers to the local state administration (local state executive body) (Lyubchenko, 2010). To address this issue, it is proposed to introduce in Ukraine the institution of prefects - representatives of the state, who will exercise control over local governments, and to restore the right of regional representative bodies to form their own executive bodies. However, these intentions have not yet been realized.

Some cities combine municipal and regional levels of government. In France, Paris has the status of a commune and department. The representative bodies of the Scandinavian capitals have a similar status. In federal states, large cities can combine the powers of the federation and local government (Berlin, Free Hanseatic City of Bremen, The free and Hanseatic city of Hamburg in Germany; Vienna in Austria, etc.) (Shvets, 2014; Petryshyn, 2014; Pittsyk, 2006). In the Ukrainian self-government, the cities of Kyiv (as the capital of Ukraine) and Sevastopol have a similar dual municipal-regional status. In Kyiv, the mayor heads both the representative body of local self-government (city council) and the local body of state executive power (city state administration).

Representative bodies at the municipal level include local (or municipal) councils (Italy, Latvia, Lithuania, the Netherlands, Austria, Belgium, Bulgaria, Greece, Germany), local (or 
municipal) meeting (Georgia, Japan), assembly (Portugal, Serbia, Czech Republic, Sweden), maslikhat (Kazakhstan), public representation (Slovakia), acting on behalf of the population of the respective self-governing unit (Kaminska, 2014; Pittsyk, 2006; Lyubchenko, 2010; Ladychenko, 2020). In every community of Ukraine such a representative body is a village, settlement, city council.

Representative bodies include members with different names: deputies (Slovakia, Ukraine), municipal councilors (France, Spain, etc.) (Kaminska, 2014; Popko, 2016). Representative bodies are always collegial and are elected in municipalities depending on the population, economy, social infrastructure, land and landscape nature of the jurisdiction, etc. In addition, the size of the council depends on whether the councilors work permanently or on a voluntary basis. Composition of municipal councils in France - from 9 to 69; in Germany - from 5 to 80; in Italy - from 15 to 80; in the Netherlands - from 7 to 45; in Norway - from 13 to 85; in Denmark - from 5 to 35; etc. (Shvets, 2014; Kaminska, 2014; Rudenko, 2017; Pittsyk, 2006; Ladychenko, 2020). In Ukraine, the composition of local councils depends on the number of residents living in the respective administrativeterritorial units and can range from 22 to 120 deputies.

The term of office of representative bodies of local self-government is a matter of constant discussions at the legislative level and among scientists. Frequent elections are expensive for local budgets, and a short period of time does not allow to enter the course of affairs, but such a body is easier to control. A longer term is more economical from a financial point of view and allows representatives not to constantly think about their re-election, but then such a body is less controlled and has an increased risk of abuse. The frequency and procedural issues of elections should be regulated at the legislative level. After all, regional elites are often less democratic than the central government, and at the first opportunity try to integrate local authorities into the mechanism of their own enrichment (Petryshyn, 2014; Kaminska, 2014; Pittsyk, 2006; Lyubchenko, 2010).

The term of office of all local councils in Ukraine has been increased from 4 to 5 years since 2006. As a rule, in local self-government the whole composition of a representative body is re-elected, although there are cases of re-election of a part of their composition. Municipal councils in foreign countries are elected for different terms. In Austria, councils are elected for 4 to 6 years (in different countries in different ways). In Sweden, the term of office of municipal councils (meetings) is 4 years, the district council (landsting) - 3. In Germany, the term of office of representative bodies of local government is 4 or 5 years (Petryshyn, 2014; Kaminska, 2014; Pittsyk, 2006; Lyubchenko, 2010).

Municipal councilors in classical democracies operate mainly on a voluntary basis, do not enjoy any privileges or immunities, but are legally responsible for their decisions if they cause material damage or moral damage (Ladychenko, 2019). Municipal councilors do not keep their salaries for the duration of their municipal duties. This means that these responsibilities are financially feasible only for those who have a decent income. In France, the municipal council may (but is not obliged to) set a certain salary for its members (Lyubchenko, 2010).

The main form of work of representative bodies is sessions. They are convened more often in the lower bodies than in the regional ones. In France, the law requires councils of communes to meet regularly four times a year, and general councils of departments twice. In Sweden, the frequency of sessions of lower-level representative bodies of local self- 
government is set by them, and sessions of middle-level councils must be held at least once a year. In addition to regular sessions, extraordinary sessions may be convened at the request of the government, the relevant state representative on the ground, members of the local representative body and on the initiative of the local population (Rudenko, 2017; Pittsyk, 2006).

Within their competence, local representative bodies may form commissions (committees), which are divided into permanent and temporary, sectoral, functional and territorial. Standing committees are formed after the election of the council and function throughout the term of office of the council. Temporary (specialized) committees are created as needed to solve or study a particular problem and are dissolved after completing their task and the relevant report to the council. Their creation gives the system of local government flexibility, taking into account changing circumstances, and the ability to solve a problem that does not belong to the competence of the standing committees (Shvets, 2014; Rudenko, 2017; Pittsyk, 2006).

Mandatory committees are appointed in accordance with the law of the country, by decision of the council, taking into account its ability to perform certain functions. Swedish municipalities should form committees on education, environment and health, construction, social welfare, and elections. Czech municipalities form only a finance and control committee. Norwegian city councils form standing committees on construction development, education, social security, whose members are both council deputies and local officials (Shvets, 2014; Rudenko, 2017; Pittsyk, 2006).

Sectoral (vertical) committees are created in the direction of municipal activities (health care, education), while functional (horizontal) committees perform service functions in relation to other council committees and resolve complex, special issues (personnel committees, legal, financial committees, etc.). In Anglo-Saxon law, where there is often no single head of the executive branch, the so-called executive committee plays an important role. It usually consists of the chairmen of other council committees or leaders of party factions. According to R.M.Pannet, such a committee acts as a kind of cabinet that coordinates and controls the work of various committees. If such a committee is not formed, the issue of coordination is carried out by such functional committees as finance and economic (Shvets, 2014; Rudenko, 2017; Pittsyk, 2006).

Territorial commissions unite council members elected from a particular district and are responsible for that district. In addition, various advisory commissions may be formed, which include not only municipal councilors but also representatives of the population. In France, for example, such commissions are called "non-municipal". They allow members of local councils and ordinary citizens to exchange views on various topical issues. These commissions are not considered official bodies of the commune, but are a tool to involve the population in various administrative issues (Shvets, 2014; Pittsyk, 2006).

Committee members are most often elected by local representative bodies at their meetings. When making specific decisions, the desire to ensure heredity in the activities of committees is decisive (i.e. the appointment of a person mainly to the committee in which he previously participated); balance between representatives of political parties in proportion to the number of their factions in the council (but one-party committees are prohibited); balance between different territories that are part of this administrativeterritorial unit; taking into account the personal interests and preferences of council 
members, as well as their seniority; uniform workload of all council members (Shvets, 2014; Pittsyk, 2006).

Most committee members should be members of local councils, although external experts are sometimes allowed (co-optation). Hungarian legislation allows for the possibility of including in any committee specialists in its profile who are not members of this council (Shvets, 2014; Pittsyk, 2006). In Ukraine, the representative bodies of local selfgovernment in organizational and structural terms meet the basic European democratic standards. On the issue of potential development of representative bodies of local selfgovernment P.M.Lyubchenko proposes to reduce the number of local council deputies by about half. As for the term of office of representative bodies, it makes sense to borrow European experience and at the legislative level to fix the norm according to which they should be updated: (a) village and settlement councils - completely every 3 years, (b) city and district councils - half every 2 years, ( c) district and regional councils - by a third annually (Lyubchenko, 2010).

Executive bodies of local self-government are such bodies and officials of local selfgovernment that are called upon to implement the decisions of representative bodies.

The executive bodies are classified as follows:

1) sole executive bodies - the head of the executive apparatus of local government - mayor (France), sindaco (Italy), lord mayor (Great Britain), burgermeister, oberburgermeister (Germany), the alcald (Spain, Portugal), starosta (Slovakia, Czech Republic), clerk (Ireland), wuyt, burmistrz, president of a large city (Poland) and in some countries he may also combine the powers of the chairman of the representative body. Within the system "board - manager" the functions of the head of the executive power the council transfers to the professional manager-manager - director;

2) collegial executive bodies - the executive council (Norway), the council (the Czech Republic), the chancellery, the bureau, the magistrate (Germany), the junta (Italy), the board of aldermen (Belgium, the Netherlands); executive bureaus (Lithuania); standing or executive committees (Denmark, Iceland, Latvia, Sweden), which are subordinate to the representative bodies, coordinate the work of the executive apparatus of local selfgovernment, in the period between council sessions may exercise some powers of representative bodies;

3) specialized executive bodies, divided between the chairman and the collegial executive body, consisting of municipal employees - departments, inspections, services, departments (Shvets, 2014; Kaminska, 2014; Pittsyk, 2006).

The structure of local self-government uses a broad concept of "executive apparatus", which includes both the executive body of general competence (mayor, collegial executive bodies) and subordinate bodies of sectoral and special competence (departments, bureaus) (Shvets, 2014; Kaminska, 2014; Pittsyk, 2006).

The executive body may perform the functions of state administrations. This is typical of Germany, France and other countries, where the executive body has a dual status: local government and the lower echelons of the executive branch (implements national regulations, ensures order and security, registration of civil status, issuance of various permits). The French mayor, as a representative of the commune, convenes and prepares meetings of the municipal council, sets the agenda, prepares draft decisions, chairs, is the chief administrator of local revenues, concludes agreements, acts in court on behalf of the 
commune. As a representative of the state administration, he registers acts of public status, promulgates laws and other acts, monitors their implementation, ensures the conduct of elections, censuses. The mayors of Italy function in such a double capacity (Shvets, 2014; Kaminska, 2014; Pittsyk, 2006).

\section{Ways to Form Executive Bodies of Local Self-Government}

Given the importance of local self-government for public administration, in world practice there are a number of ways to form executive bodies on the ground:

- by election as a representative body;

- by direct election by the population;

- by appointment by the state;

- in a combined way.

Local representative bodies may elect an executive body (often a single person, less often a collegial one) from among its members. In the German lands, the mayor is elected by the population or the council, but has greater powers: to protest the council's decisions, to suspend their implementation, and so on. This is a senior official of local government, a representative of the government of the land (Shvets, 2014; Kaminska, 2014; Pittsyk, 2006; Rudenko, 2017).

The election of a sole executive body (head of the executive staff) by the council is typical of Austria, Denmark, France, the Czech Republic, and Spain. In France, for example, a municipal council elects a mayor and his deputies from among its members for six years. In communes with a population of more than 3.5 thousand inhabitants, where the election of councilors is held on party lists, the mayor is the person who heads the party list. The French mayor exercises his powers under dual control - the municipality and the prefect of the relevant department (Shvets, 2014; Kaminska, 2014; Pittsyk, 2006; Rudenko, 2017). Collegiate executive bodies are mainly elected by representative bodies of local selfgovernment. In Italy, the regional council at its first meeting elects from among its members the chairman and other members of the junta - the executive body of the council, which implements the decisions of the council, submits to its meeting draft regional plans, budgets, development programs, coordinates their implementation, manages their property. In some German lands (Hesse, Bremen, Kiel, Frankfurt) at the grassroots level form a collegial body - the magistrate. It is elected by a representative body from among its members and includes from 6 to 12 members, including the mayor. In Finland, the municipal representative body - the meeting of commissioners - elects the municipal head - the mayor, who is the highest official of the municipality and is responsible for conducting economic affairs. However, the executive body of the commune is not the mayor, but a collegial body - the municipal administration, which is also elected by the meeting of commissioners. Collegiate executive bodies of local councils function in Belgium, the Netherlands, Sweden, large cities of Denmark (Shvets, 2014; Kaminska, 2014; Pittsyk, 2006; Rudenko, 2017).

In Ukraine, village, town, and city mayors are elected directly by the population, headed by representative and executive bodies, and have powerful powers in their "arsenal" (the right of "veto", the right to take into account the vote, are budget managers, propose candidates for elected officials for election or approval by the council, as well as appoint 
and dismiss all other local government officials), which gives reasonable grounds to believe that the use of local government at the community level is the system "strong mayor council" (Startsev, 2020).

Much less often, a collegial executive body is elected directly by the population. In Portugal, the collegial body of the municipality is the municipal chamber, whose members are elected by citizens living in the area. This chamber consists of 5 to 11 people (17 people in Lisbon) (Startsev, 2020; Pittsyk, 2006; Fenenko, 2004).

In Ukraine, such elected officials include elders (Ladychenko, 2019). But today these officials are no longer elected by the population, but by a representative body (council) on the proposal of the mayor. In addition, the search for a "place" for these officials in the system of local self-government continues, as elders were introduced as a "compromise" for the employment of the heads of those communities that ceased to exist upon unification. Today, when the administrative-territorial division into communities in Ukraine is completed, as a result of continuing the decentralization reform, the state should assign a certain role to the elders: either these officials will be heads of territorial "offices" to provide administrative services to the population of eldership districts, or they mast be territorial "assistants" of village, settlement, city mayors, on whose exclusive proposal they are elected by community councils.

In this regard, the example of Poland is interesting, where gminas are divided into a kind of auxiliary units: soltists - in rural areas, and neighborhoods - in cities and cities, if more than one in the gmina. The principles of formation of such auxiliary units are regulated by the charter of the commune, and the organization and powers of the soltists / microdistrict are established by the commune council. The village assembly is a decision-making body executed by the soltis, elected by the inhabitants of the same unit. In neighborhoods, decisions are made by the council, and the executive body is the board with the head. The charter may also establish that the decision-making body in the neighborhood is the general meeting of residents (Vilizhinsky, 2014).

In addition, Swedish legislation on local self-government is noteworthy, which provides greater autonomy in creating their own organizational and legal forms of local selfgovernment at the community and district levels, which are formalized into three models of community governance: sectoral, territorial and functional. The latter, the functional model, is of interest because the customer function is separated from the management function. The committee is formed as a body of the customer, not the management. Thus, on a competitive basis, the company or municipal service that will organize the work of public transport is determined. Its function is to pay for these services. This improves and reduces the cost of services, reduces the influence of elected representatives on the activities of the community (Tkachuk, 1997; Kaminska, 2014; Ladychenko, 2013).

Relationships between representative and executive bodies vary from country to country. In some, the distribution of power at the local level is not recognized and the representative bodies have the full power given to local self-government. The official head of the municipality is elected by the council, can act only on its behalf and to perform its functions (Denmark, Finland, where the system of "weak mayor - council"). Executive bodies in these cases are subordinate to the representative body (Shvets, 2014; Kaminska, 2014; Ladychenko, 2015).

The executive body may not be elected, but appointed by the state. This practice is found 
in Belgium, the Netherlands, and Luxembourg, where the mayor or burgomaster is appointed by the head of state on the proposal of the relevant municipal council. For example, in Luxembourg, the executive bodies of local self-government are the boards and mayors (burgomasters), who are also local public authorities, who are usually appointed by the head of state on the recommendation of their councils. In the Netherlands, mayors and royal commissioners in the provinces are appointed by the central government after consultation with the representative bodies of communities and provinces (Shvets, 2014; Kaminska, 2014; Pittsyk, 2006; Fenenko, 2004).

\section{Functions of Bodies of Local Self-Government}

In Germany, the system of "strong mayor - council" is used, where there is a clear division of power on the ground. Executive bodies have relative independence and have counterbalances to the policies of representative councils. There is a tendency to clearly delineate their powers. In Belgium, the executive bodies of municipal councils oversee the management of local affairs, revenue collection, implement the decisions of the council, manage public property and personnel of municipal services (Shvets,2014: Kaminska, 2014).

In the scientific community, it is widely believed that to ensure sustainable development, it is important to clearly delineate the functions of bodies, i.e. the most common areas of development and ensure the normal functioning of the state. This is supported by the "system of checks and balances", which in a decentralized state should operate in vertical and horizontal directions (Ladychenko, 1998; Kaminska, 2014).

To ensure sustainable development, it is important to balance the activities of structural elements of local self-government through the division of powers between representative and executive bodies. But it is also worth combining control over local governments not only by the state (introduction of the institution of prefects), but also by the community itself. This option is possible, including through the short-lived local elections (2-3 years), as well as the direct election of more municipal employees by communities (not only deputies and chairmen, but also key heads of executive services).

Each country throughout its history through trial and error creates its own regulatory framework that regulates the activities of local governments. Ukraine is no exception (Pittsyk, 2006). In some countries, the status of local governments is determined by the national constitution and organic laws, and in others - the constitution, the laws of the federation, municipal charters and statutes (Kaminska, 2014). In some countries, the activities of municipalities are regulated by specialized codified legislation. In France the document that more specifically regulates the activities of communes is the Code of Collective Territorial Units of 1996 (Petryshyn, 2014).

In Ukraine, there are many laws in this regard, which in one way or another regulate the activities of local self-government: "On local self-government in Ukraine" (1997), "On service in local self-government bodies" (2001), "On self-organization bodies of the population" (2001), "On the status of deputies of local councils" (2002), "On associations of local self-government bodies" "(2009)," On the cooperation of territorial communities "(2014)," On the voluntary association of territorial communities "(2015). But the state is not standing still and the President of Ukraine has already announced the design of a single 
codified legislative act on local self-government - the Municipal Code of Ukraine (The President creates the Congress of Local and Regional Authorities, 2020). The completion, which will confirm the consolidation of the results of local government reform and decentralization, after the already approved irreversibility of the European and EuroAtlantic course of Ukraine, will be amendments to the Constitution. Therefore, in our opinion, for local self-government, along with the principle of subsidiarity, the principle of division of powers between representative and executive bodies of local selfgovernment should be constitutionally enshrined. The classification of representative bodies of local self-government in Ukraine into village, settlement and city councils today is rather a tribute to tradition, as all communities are essentially equal, have the same organization and set of powers, which are uniformly prescribed in organic law. This is the realization of the concept of a capable community.

\section{Conclusions}

Summing up the study, we can state that the reform of the administrativeterritorial system in Ukraine has taken place. However, the reform of local self-government and decentralization is not complete. The issues of regional self-government and its executive bodies, as well as the optimal and balanced organization of local self-government at the community level remain unresolved. Ukraine needs to build its own model of local self-government, in which its bodies and officials will be accountable both to the state and to their own communities. From this, local self-government needs to be reformed on the principles of democracy and division of powers.

As for the further development of local self-government in Ukraine, at the present stage of implementation of the pan-European trend through the gradual transition from community management systems to a system of "good governance" - democratic, effective, adequate to modern tasks, transparent, public and accountable to the public of local and regional government, the state should implement democratic methods of selfgovernment of Western countries, including through effective state control, election of key local government officials, transition from self-government from "communal" to modern "municipal", codification of the legislation on local self-government and balancing the status and scope of powers of representative and executive bodies, and local selfgovernment officials. As well as the consolidation of achievements in the Constitution of Ukraine and the unification of numerous and scattered legislation in one organic law - the Municipal Code of Ukraine.

\section{References}

Council of Europe. Decentralization and public administration reform in Ukraine. (2020). URL: http://www.slg-coe.org.ua/goal-and-objectives/

Dubchak S., Goshovska V., Goshovskyi V., Gulac O., Svetlychny O. (2020) Legal regulation of ensuring nuclear safety and security in Ukraine on the way to European integration. European Journal of Sustainable Development. Volume 9, № 1, pp. 406-422. URL: http://ecsdev.org/ojs/index.php/ejsd/article/view/994/990.

Fenenko, Yu.V. (2004). Municipal systems of foreign countries: legal issues of social security. Moscow: MGIMO-University. 
for 2018-2021, approved by the Committee of Ministers of the Council of Europe on 21 February 2018. URL: https://rm.coe.int/coe-action-plan-for-ukraine-2018-2021-ukr/1680925bec

Funta, R., Golovko, L., Juriš, F. (2016). Európa a európske právo. Bratislava: Iris.

Golovko, L. (2017) Implementation of EU Water Policy in Ukraine: Problems and Perspectives. Proceedings of the $8^{\text {th }}$ International Scientific Conference Rural Development, 605-610.

Golovko, L. (2019). Adaptation of Ukrainian Legislation to EU Law in the Field of Food Safety, Proceedings of the International Conference on European Dimensions of Sustainable Development, April 23-24, 2019. - Kyiv: NUFT, 60-61.

Golovko, L. (2019). Legal Regulation of Food Security, Human. Law. Environment, Volume 10, № 1, 128-133.

Golovko, L., Kutsevych, M., Serediuk, V., Bogdan, O. (2020). Implementation of EU Environmental Policy in Ukraine: Directions and Perspectives. European Journal of Sustainable Development, Volume 9, № 4, 191-198.

Golovko, L., Yara, O., Kutsevych, M., Hubanova, T. (2019). Environmental Policy Integration in Ukraine and the EU. European Journal of Sustainable Development, Volume 8, № 3, 221-227.

Government portal. Activity. Reforms. Effective governance. (2020). URL: https://www.kmu.gov.ua/diyalnist/reformi/efektivne-vryaduvannya

Gulac, O., Dubchak, L., Iarmolenko, I., Yanchuk, J. (2019). Cooperation of Ukraine and the European Union in the ecological sector: directions and prospects. European Journal of Sustainable Development, Volume 8, № 1, 22-30.

Kachur, V., Protosavitska, L., Zasukha, L., Golovko L. (2020). The Role of Legal Culture in Maintaining Social Stability and Countering Separatist Movements: Case of Ukraine. European Journal of sustainable development, Volume 9, № 1, 294-299.

Kaminska, N.V. (2014). Decentralization of power and experience of its carrying out in foreign states . Scientific notes of the Institute of Legislation of the Verkhovna Rada of Ukraine, 4, 35-40.

Kaminska, N.V. (2014). European system of local and regional self-government and Ukraine. Kyiv: KNT.

Kidalov, S., Vitiv, V., Golovko, L., \& Ladychenko, V. (2020). Legal Regulation of Waste Management in Ukraine on the Way to European Integration. European Journal of Sustainable Development, 9(2), 422430.

Krasnova, Y., Golovko, L., Hunko, L., Medynska, N. (2020). Development of Legal Regulation of Land Ownership in Ukraine, Solid State Technology Volume: 63 Issue: 2s, 4087 - 4094. URL: http://www.solidstatetechnology.us/index.php/JSST/article/view/2570

Kutsevych, M., Yara, O., Golovko, L., \& Terpeliuk, V. (2020). Sustainable Approaches to Waste Management: Regulatory and Financial Instruments. European Journal of Sustainable Development, 9(2), 163171.

Ladychenko, V. (2007). Humanistic foundations of the organization of state power: a monograph. Kyiv: Kyiv National University of Trade and Economics, 2007. - 435 c.

Ladychenko, V. (2015). The Place of the Right to Drinking Water in the Human Rights System. Scientific Notes of the International Humanities University, 23, 62-65.

Ladychenko, V., Golovko L. (2018). The Right to Access to Environmental Information in Ukraine and the EU. European Journal of sustainable development, Volume 7, № 3, 455-459.

Ladychenko, V., Golovko, L. (2013). Legal Regulation of the Common Agricultural Policy in the EU. International Scientific Electronic Journal Earth Bioresources and Quality of Life, 3. Retrieved from: http://www.gchera-ejournal.nubip.edu.ua/index.php/ebql/article/view/102

Ladychenko, V., Golovko, L. (2015). Legislative support for drinking water supply in the United States. Scientific Notes of the Institute of Legislation of the Verkhovna Rada of Ukraine, 5, 39-43.

Ladychenko, V., Golovko, L. (2017). Implementation of European Environmental Policy in Ukraine: Problems and Prospects. European Journal of Sustainable Development, Volume 6, Issue 3, 333-339

Ladychenko, V., Golovko, L. (2019). Achieving sustainable development through environmental accounting and disclosure of environmental information: experience of Ukraine and the EU. Sustainable development under the conditions of European integration: collective monograph, Ljubljana, Slovenia. Part II., p.182-194.

Ladychenko, V., Golovko, L., Kapplová, O. (2019). Municipality as Regulator of Household waste Management. Scientific Papers of the Legislation Institute of the Verkhovna Rada of Ukraine, 5, 38-45.

Ladychenko, V., Melnychuk, O., Golovko, L., Burmak, O. (2020). Waste Management at the Local Level in the EU and Ukraine. European Journal of Sustainable Development, Volume 9, № 1, 329-329. 
Ladychenko, V., Melnychuk, O., Yara, O., Kanaryk J. (2019). International Mechanism of the Environmental Information Access and Cooperation Framework for Climate Change Protection. European Journal of Sustainable Development, Volume 8, № 4, 131-139.

Ladychenko, V., Yara, O., Golovko, L., Serediuk, V. (2019). Groundwater Management in Ukraine and the EU. European Journal of Sustainable Development, Volume 8, Issue 1, 31-39

Ladychenko, V., Yara, O., Uliutina, O., Golovko, L. (2019). Environmental Liability in Ukraine and the EU. European Journal of Sustainable Development, Volume 8, № 2, 261-267.

Ladychenko, V.V. (1998). Separation of powers: theory and practice. - Kyiv: Ukraine. 1998. - 38p.

Ladychenko, V.V. (2019). Elders as officials of the system of local self-government in Ukraine: historical and legal aspect. Scientific notes of the Institute of Legislation of the Verkhovna Rada of Ukraine, 2, 817.

Ladychenko, V.V., Yemelyanenko, K.O. (2020). Legal bases of activity of local governments of Ukraine and the Republic of Kazakhstan. Kyiv: NULES of Ukraine.

Lyubchenko, P.M. (2010). Comparative legal analysis of representative bodies of local self-government in Ukraine and foreign countries. Problems of legality, 109, 54-64.

Maksymenko, Yu. P. (2020). Status and powers of village, settlement, city mayors in the system of local selfgovernment of Ukraine. Journal of Kyiv University of Law, 4, 144-150

On decentralization reform. General information. (2020) URL: https://decentralization.gov.ua/about

Petryshyn, O. (2014). Legal principles of local self-government in foreign countries and Ukraine: theoretical-legal and comparative analysis. Kharkiv: Pravo, 2014.

Pihul, N.G., Lyuta, O.V. (2016). Foreign experience of decentralization reforms. Global and national economic problems, 9, 684-688.

Pittsyk, M.V. (2006). Local self-government: a review course (teaching program for employees of local selfgovernment). URL: http://librarysnu.at.ua/misceve_samovrjaduvannja_ogljadovij_kurs.doc

Popko, V.V. (2016). Iberian model of local self-government. Journal of Kyiv University of Law, 3, 390-395.

Rovynska, K. (2013). General principles of local self-government organization: theoretical and comparative analysis. Theoretical and applied issues of state formation, 12. URL: http://nbuv.gov.ua/UJRN/tppd_2013_12_18

Rudenko, O.M., Kozyura, I.V., Tkalenko, N.V., Margasova, V.G. History and theory of local self-government. (2017). Kyiv: Condor Publishing House, 2017. - 226 p.

Shvets, G. Yu. (2014). World practice of organization of work of representative and executive bodies of local self-government. Scientific journal of the Uzhbhorod national university. Series: Law, 27 (3), 186-190.

Startsev, Ya. Yu. (2020). State and municipal administration in foreign countries. URL: https://www.c-zs.ru/doc/build/study/starcev-ya.yu.-gosudarstvennoe-i-municipalnoe-upravlenie-v-.pdf

Sumy City Council Information Portal. (2016). Basic principles of local self-government in the USA and election of some bodies and officials. URL: https://smr.gov.ua/en/2016-03-14-08-10-17/pravovadopomoha/populiaryzatsiia-pravovykh-pozn/18186-bazovi-printsipi-mistsevogosamovryaduvannya -v-ssha-ta-vibornist-deyakikh-organiv-i-posadovikh-osib.html

The President creates the Congress of Local and Regional Authorities under the President, the first task of which will be to develop the Municipal Code of Ukraine. (2020). URL: https://www.president.gov.ua/news/glavaderzhavi-stvoryuye-kongres-miscevih-ta-regionalnih-vla-66785

Tkachuk, A., Brown, T., Agranoff, R. (1997). Local self-government: world and Ukrainian experience. Kyiv: Testament.

Vasiuk O., Gulac O., Shust V., Marchenko S., Halai A., Halai V. (2020) Legal Grounds for Social Work Organization in Rural Communities of Ukraine. European Journal of Sustainable Development. Volume 9, № 3, pp. 503-512. URL: http://ojs.ecsdev.org/index.php/ejsd/article/view/1099/1079.

Vilizhinsky, V.M. (2014). Reforming the system of local self-government in Poland: experience for Ukraine. Public administration and local self-government, 2 (21), 265-277.

Yara, O., Brazheyev A., Golovko L., Bashkatova V. (2021). Legal Regulation of the Use of Artificial Intelligence: Problems and Development Prospects. European Journal of Sustainable Development, 10 (1), 281-289.

Yara, O., Uliutina, O., Golovko, L., Andrushchenko, L. (2018). The EU Water Framework Directive: Challenges and Prospects for Implementation in Ukraine. European Journal of Sustainable Development, Volume 7, № 2, 175-182. 